\title{
MIŁOŚĆ MISJĄ RODZINY. REFLEKSJE NA KANWIE OBRAD VIII MIĘDZYNARODOWEGO KONGRESU RODZIN W FILADELFII
}

\section{WSTECP}

W dniach 22-25 września 2015 r., w ramach VIII Światowego Spotkania Rodzin, odbywał się w Filadelfii Międzynarodowy Kongres Rodzin. Tym razem jego hasłem było: „Miłość jest naszą misją: rodzina pełnią życia”. Wydarzenie to zostało zorganizowane przez Papieską Radę ds. Rodziny oraz Archidiecezję Filadelfijską. W tym naukowym spotkaniu wzięło udział prawie 20 tys. uczestników z ponad 100 krajów i była to zdecydowanie największa liczba uczestników w porównaniu z dotychczasowymi spotkaniami. Kongres stał się wielkim świętowaniem rzeczywistości rodziny, te dni jawiły się jak piękna zorza, będąca zwiastunem nowego dnia. Arcybiskup Charles Chaput, metropolita Filadelfii, określanej mianem miasta braterskiej miłości, podczas uroczystości otwarcia kongresu i światowego spotkania rodzin mówił o tym, że „Bóg przemienia świat poprzez ludzi i rodziny, które go kochają. Stąd też mamy nadzieję uczyć się od tych rodzin, jak kochać. Chcemy to czynić jeszcze lepiej niż dotychczas". Nadzieją głównego organizatora było więc, aby to spotkanie przyniosło wspaniałe owoce polegające na odnowieniu życia poszczególnych jego uczestników. Chodziło mu o odświeżenie i umocnienie miłości w małżeństwach i rodzinach. Tego dzieła jednak, jego zdaniem, może dokonać jedynie Bóg, który pragnie odbudować domowe Kościoły. 
Będzie to możliwe dopiero wówczas, gdy małżeństwa otworzą się na łaski płynące z sakramentu małżeństwa. Arcybiskup Chaput podczas liturgii mszalnej zwrócił uwagę, odwołując się do czytań (Ezd 9, 5-9), że podobnie jak Izraelici, którzy wracając do ziemi obiecanej, byli narażeni na szereg pokus, tak również i współcześni chrześcijanie są kuszeni. Tym razem pokusy te dotyczą biblijnej koncepcji rodziny oraz wierności danym sobie przez małżonków przyrzeczeniom. Stąd też istnieje potrzeba odnowienia przymierza z Bogiem, bo ono jest najważniejsze. To Bóg żywy i prawdziwy powinien być na pierwszym miejscu i od Niego wszystko powinno się zaczynać .

Natomiast arcybiskup Vinzenzo Paglia, przewodniczący Papieskiej Rady ds. Rodziny wyraził nadzieję, że spotkanie rodzin w Filadelfii podczas kongresu przyczyni się do zrozumienia, ,że małżeństwo i założenie rodziny jest o wiele lepsze od życia samotnego, od kariery i pieniędzy"2. Bóg złożył nadzieję w rodzinie, dlatego też istnieje potrzeba powrotu do źródeł, do odkrycia na nowo tej nadziei. Pan Bóg stworzył świat dla rodziny ludzkiej i całe stworzenie jest jej domem. Rodzina, która będzie żyła zgodnie z Bożym zamysłem, będzie miłowała się nawzajem, przez co będzie zmieniać świat. Stąd dobra kondycja rodziny rokuje jednocześnie dobrą jakość społeczeństwa.

Było to wielkie przedsięwzięcie, z którym wiązał się ogromny wysiłek organizacyjny i ekonomiczny. W związku z tym zrodziły się pytania, które niejednokrotnie stawiane były przez wiele osób. Czy takie kongresy są w ogóle potrzebne? Czy to daje coś konkretnego światu? Czy potrzebne jest aż takie zaangażowanie ekonomiczne w organizację tego dzieła? Czy nadzieje zawarte w wypowiedziach wstępnych organizatorów tego kongresu i światowego spotkania rodzin są zasadne? Niniejszy artykuł będzie próbą odpowiedzi na tak postawione pytania.

1 Por. A. P r y c e (red.), World Meeting of Families - Philadephia 2015, Philadephia 2015, s. 8.

2 Por. tamże, s. 9. 


\section{GENEZA ORGANIZACJI KONGRESÓW RODZIN W RAMACH ŚWIATOWEGO SPOTKANIA RODZIN}

Rok 1994 był obchodzony zarówno w całym świecie, jak i w Kościele, jako Rok Rodziny. W związku z tym św. papież Jan Paweł II zainicjował cykl światowych spotkań małżeństw i rodzin, odbywających się, podobnie jak ma to miejsce w przypadku Światowych Dni Młodzieży, w różnych miejscach świata. Odbywają się one co trzy lata. Organizatorem tych spotkań jest Papieska Rada ds. Rodziny oraz diecezja, na terenie której to wydarzenie się odbywa. Mają one na celu promocję Ewangelii rodziny oraz świętowanie prawdy na temat małżeństwa i rodziny. Pierwsze spotkanie, które zorganizowano w Rzymie, stało się wzorcem dla następnych tego typu inicjatyw. Odbywało się ono pod hasłem „Rodzina sercem cywilizacji miłości"3 i składało się z trzech części. Pierwsza z nich, inicjująca spotkanie, to trzydniowy kongres naukowy, podczas którego podejmowane były zagadnienia związane z głównym tematem całego wydarzenia. Podczas kongresu zaproszeni znawcy poszczególnych tematów wygłaszali wykłady. Odbywało się to zarówno w czasie ogólnych sesji plenarnych, jak i w trakcie spotkań w mniejszych grupach, gdzie w kolejnej fazie podejmowano dyskusję. Ta wymiana myśli i doświadczeń stała się bardzo ubogacającym wydarzeniem dla uczestników kongresu.

Drugą część Światowego Spotkania Rodzin stanowiły sobotnie spotkania w grupach językowych, które odbywały się w poszczególnych parafiach, oraz wieczór świadectw kilku rodzin w obecności papieża bądź jego oficjalnego przedstawiciela w osobie legata papieskiego. Całość stała się wielkim i wspaniałym widowiskiem na cześć Boga i rodziny, która jest Jego zamysłem.

${ }^{3}$ Zob. A. P r y b a, Rodzina szkoła wartości ludzkich I chrześcijańskich w świetle przesłania VI Światowego Spotkania Rodzin (Meksyk 2009), w: A. P r y b a (red.), Rodzina szkołą wartości, Poznań 2011, s. 156. 
Trzecia natomiast część tego niezwykłego wydarzenia to uroczysta Eucharystia z papieskim przesłaniem. Schemat spotkania, jaki został tu zaprezentowany, zastosowano we wszystkich następnych.

Kolejne, drugie z kolei Światowe Spotkanie Rodzin zorganizowano w Brazylii, w Rio de Janerio, pod hasłem: „Rodzina: dar i zobowiązanie, nadzieja ludzkości”, w roku 1997. W Roku Jubileuszowym odbyło się trzecie spotkanie, które gościło ponownie w Rzymie, a jego myślą przewodnią było: „Dzieci wiosną rodziny i społeczeństwa”. Trzy lata później, to jest w roku 2003, Międzynarodowy Kongres Rodzin i Światowe Spotkanie Rodzin miały miejsce w Manili na Filipinach. To wydarzenie opatrzono znamiennym tytułem: „Rodzina chrześcijańska dobrą nowiną na trzecie tysiąclecie". Z kolei w roku 2006 spotkanie z tej serii zostało zorganizowane w hiszpańskiej Walencji. Motto tego międzynarodowego przedsięwzięcia brzmiało: „Przekazywanie wiary w rodzinie”. W roku 2009 kongres odbył się w mieście Meksyk, a jego myślą przewodnią było zdanie: „Rodzina szkołą wartości ludzkich i chrześcijańskich”. Kolejne, VII Światowe Spotkanie Rodzin, odbywało się w Mediolanie od 30 maja do 3 czerwca 2012 roku pod hasłem: „Rodzina, praca, świętowanie”. I wreszcie, ostatnie jak dotychczas, będące przedmiotem szczególnej analizy niniejszego artykułu, zorganizowano w Filadelfii pod hasłem: „Miłość jest naszą misją: rodzina pełnią życia”, w dniach 22-27 września 2015 r.

\section{RODZINA PRAWDZIWĄ WARTOŚCIĄ WSPÓLCZESNEGO ŚWIATA}

Celem spotkań wielkich rzesz ludzi, pragnących pochylać się nad zagadnieniem małżeństwa i rodziny, jest umocnienie świętych więzów rodzinnych. Chodzi również o to, by ukazać na nowo prawdę na temat małżeństwa i rodziny. Rodzina ze swojej natury posiada wartość, jest wartością samą w sobie. Stąd też temat i logo spotkania, a więc i kongresu, ma za zadanie podkreślić wartość rodziny zarówno dla poszczególnych jej członków, jak również dla całego społeczeństwa. 
W Filadelfii logo światowego spotkania rodzin obejmowało dzwon, widniejący nad nim krzyż oraz na tle dzwonu pięć osób różnej wielkości. Dzwon ów nawiązuje do Dzwonu Wolności, który jest nieoficjalnym symbolem miasta Filadelfia. Jego dźwięki zwołały w roku 1776 mieszkańców miasta oraz obywateli nowopowstającego państwa Stanów Zjednoczonych, aby wysłuchali Deklaracji Niepodległości, dzięki czemu dzwon ten utrwalił się w świadomości narodowej Amerykanów.

Umieszczenie w logo Spotkania Rodzin tego charakterystycznego dla Amerykanów symbolu miało na celu z jednej strony podkreślenie roli Filadelfii jako miasta broniącego praw człowieka i wolności religijnej, z drugiej natomiast strony miał on symbolizować liczne dzwony na całym świecie, głoszące Dobrą Nowinę i przywołujące jednocześnie rodziny do kościoła.

Drugim elementem logo Kongresu jest krzyż, który został umieszczony w centralnym miejscu nad dzwonem. Tym samym podkreślono, że Chrystus w życiu małżeństwa, rodziny i Kościoła winien zajmować centralne miejsce.

Na tle dzwonu znajduje się pięć postaci. Różnią się one wielkością i wiekiem, ponieważ reprezentują osoby pełniące różne role w jedności, jaką jest rodzina. Chodzi tu o rodziców, dzieci, rodzeństwo, dziadków i babcie, wujków i ciotki. Warto też zwrócić uwagę na kolorystykę logo. Są to ciepłe barwy, charakterystyczne dla jesieni, nawiązujące do okresu, w którym odbywał się Kongres ${ }^{4}$.

Spotkanie rodzin w Filadelfii i odbywający się w ramach niego Międzynarodowy Kongres Rodzin miały na celu, podobnie jak miało to miejsce podczas poprzednich tego typu wydarzeń, odkryć na nowo prawdę o małżeństwie i rodzinie, ukazując jednocześnie jej wielką wartość.

4 Por. A. P r y c e (red.), World Meeting of Families - Philadephia 2015, dz. cyt., 2015, s. 63. 


\section{PELNIA ŻYCIA RODZINY}

Odkrywanie na nowo prawdy na temat małżeństwa i rodziny, ukazywanie jej godności i wartości, zapalanie entuzjazmem podczas poszczególnych wypowiedzi prelegentów miało miejsce przez cały okres kongresowego namysłu. Niektóre z wypowiedzi, które zostaną tu przywołane, stały się dla autora tego tekstu inspiracją do własnych przemyśleń, które znajdą poniżej swój wyraz.

Wykład inauguracyjny pt.: „Życie na obraz Boga: dla radości i miłości” wygłosił biskup pomocniczy diecezji Los Angeles, Robert Barron. Podkreślał on w swoim wystąpieniu podstawową prawdę o przeznaczeniu ludzi do życia z Bogiem. Stało się tak dzięki inicjatywie samego Boga, który posłał swojego Syna, aby ludzie mieli udział w Jego życiu. Niestety, wielu spośród nich nie czci jednego Boga, nie oddaje Mu należnej czci, nie adoruje Go. Często natomiast idzie za innymi bogami, takimi jak przyjemność, pieniądz, alkohol, narkotyki, seks, władza. Te bożki nie zaspokoją jednak najgłębszych pragnień ludzkich.

Niekiedy ludzie stawiają sobie pytania dotyczące przyczyn zeświecczenia świata. Dlaczego tak się dzieje? Bo katolicy nie chodzą do Kościoła - odpowiadał - bo rodziny katolickie nie uczestniczą w życiu sakramentalnym. Wielu katolików zatraciło poczucie misji. Stad istnieje potrzeba powrotu do źródła. Rodzina winna na powrót stać się wspólnotą modlitwy, winna powrócić do regularnego uczestniczenia w niedzielnych zgromadzeniach liturgicznych, do żywego uczestnictwa w życiu sakramentalnym. Ponadto rodzina powinna przekazywać podstawowe prawdy moralne, w niej powinny być rozwijane cnoty moralne. I taka rodzina, która adoruje Boga, która oddaje Jemu cześć, może iść w świat, aby go uświęcać. Rodzina nosi bowiem w sobie obraz Boga. Ma go coraz bardziej odkrywać i urzeczywistniać, by następnie nieść Go światu 5 .

Przypomniane tu podstawowe prawdy i sposób ich przekazu tchnęły nadzieją i entuzjazmem. Boże powołanie, Boża miłość

5 Tamże, s. 32. 
w konkrecie historii i realizmie życia poszczególnych ludzi, małżeństw i rodzin otwartych na żywego Boga, dokonuje niezwykłych zmian w ich życiu. Dzięki odpowiedzi na inicjatywę Boga człowiek zaspokaja najgłębsze pragnienia, jakie odnajduje w głębi swej duszy. Staje się tym, kim być powinien. „Trzeba, aby rodziny naszych czasów powstały! Trzeba, aby szły za Chrystusem!"6.

Kardynał Robert Sarah, prefekt Kongregacji ds. Kultu Bożego i Dyscypliny Sakramentów przypomniał, że rodzina jest światłem dla świata, który jest zatopiony w mroku grzechu. W tym wszystkim jednak należy dostrzegać niesamowitą dobroć Boga, który stworzył wszechświat dla człowieka. Stworzył człowieka na swój obraz, na obraz Trójcy, co jest swoistego rodzaju imperatywem dla samego człowieka, by ten dawał się drugiemu na miarę Boga7.

Rodzina jest szczególnie zagrożona ze strony złego ducha, który próbuje wmówić człowiekowi, że „Bóg chce ciebie ograniczyć, On nie chce, abyś się spełnił”. Przyjęcie tego toku rozumowania prowadzi do zła, które przejawia się w różnego rodzaju przemocy, uzależnieniach, aborcji, eutanazji czy związkach tej samej płci roszczących sobie prawo do miana małżeństwa i rodziny. Inną konsekwencją przyjętej przez ludzi propozycji szatana jest zmiękczanie nauki Kościoła na temat małżeństwa i rodziny. A przecież może być inaczej. Człowiek wcale nie musi przeżywać syndromu Kaina, którego charakterystyczną cechą jest zazdrość, przeciwnie, może przejść do życia w Chrystusie. Do tego jednak potrzebuje rachunku sumienia, postanowienia poprawy i przyjęcia Bożego miłosierdzia. Radość Ewangelii to radość płynąca z Bożego miłosierdzia. Jest to możliwe, trzeba jednak rozpocząć nową drogę życiem w Duchu Świętym. Odnosi się to do każdego członka rodziny. Bóg bowiem pragnie wypełnić każdego Duchem Świętym, to jest miłością. W ten sposób pragnie

6 J a n P a w e ł II, Adhortacja apostolska Familiaris consortio, nr 86, Watykan 1981.

7 Por. A. Pryce (red.), World Meeting of Families - Philadephia 2015, dz. cyt., s. 32 . 
człowiekowi dziś okazywać swoją miłość, której najpełniejszym wyrazem było oddanie za niego życia.

Rodzina jest powołana do miłości, i to miłości do końca. Oczywiście, trzeba tu jednocześnie dodać, że każdy chrześcijanin jest powołany do miłości. Warto w tym miejscu odwołać się do sposobu życia Kościoła pierwotnego, którego charakterystyczną cechą była miłość. Wówczas ludzie mieli taką wiarę i miłość, która przemieniała świat. Współcześnie potrzeba również doświadczenia wiary i miłości, i właśnie chrześcijańska rodzina winna ukazywać ją światu. Wspomniana tu miłość potrzebuje jednak przestrzeni, w której będzie praktykowana. Bóg wybrał do tego szczególnie rodzinę, aby w niej ona rosła, aby w niej było życie Boże. To w rodzinie Bóg winien być uwielbiony. W niej w sposób szczególny winno być również praktykowane przebaczenie. Tam także powinno doświadczać się jedności dzięki wzajemnemu oddaniu i działaniu Ducha Świętego, dzięki trosce o słabych i walce z egoizmem. Jest możliwe, by rodzina była pięknym przykładem wręcz heroicznych postaw miłości, co w praktyce może rozjaśnić wszelkie ciemności. Dzięki temu, że rodzina promieniuje światłem, które jest wynikiem przyjętej miłości Bożej i praktykowanej w codzienności miłości poszczególnych członków rodziny, inni ludzie mogą również odnaleźć to światło. W praktyce dokonuje się to poprzez przyjęcie Słowa Bożego, przebaczenie, poprawę życia ${ }^{8}$.

Prof. Helen Alvaré, jedna z prelegentek Międzynarodowego Kongresu Rodzin, wyraziła swą wdzięczność Bogu za wiarę w Jego dobroć i wielkość, która również się ujawniała - jej zdaniem - w doświadczeniu tego naukowego spotkania. W swej wypowiedzi zachęcała uczestników kongresu do spojrzenia w przyszłość. Punktem wyjścia do tego była zachęta do powrotu do źródła, to jest do Bożego zamysłu. To Bóg stworzył człowieka jako mężczyznę i kobietę. Stworzył go do życia we wspólnocie miłości, ofiarowując mu płeć wraz z darem płodności. Samotność, życie tylko w wymiarze tego świata, ograniczenie się do zaspokojenia podstawowych egzystencjalnych

8 Por. J a n P a w e ł II, List do Rodzin Gratissimam sane, nr 14, Watykan 1994. 
potrzeb, fascynacja materializmem i konsumpcją, nie są Bożym zamysłem. To rozwiązania ludzkie, którymi kieruje się wielu. Te rozwiązania prowadzą człowieka do degradacji i zniewolenia.

Warte uwagi w tej wypowiedzi było zdanie dotyczące podobieństwa ludzi pomiędzy sobą. Pragnienia Boga wobec ludzi nie są przyczyną konfliktów. To ludzkie ambicje są częstą przyczyną zamknięcia się na nowe życie. A przecież człowiek nie może żyć tylko dla siebie, nie może się zamykać w swoim egoizmie. Aktualne tendencje obowiązujące we współczesnych społeczeństwach kładą nacisk na karierę indywidualną, na tzw. samorozwój. Młodzi ludzie w tej sytuacji stawiają sobie pytanie dotyczące zasadności postaw prokreacyjnych, nie są gotowi na zrodzenie potomstwa w kontekście dopiero co zakończonych studiów i rozpoczętej kariery. Ponadto pojawiają się lęki dotyczące życia w związku. Kobiety nie chcą być wykorzystane, ludzie boją się również brać odpowiedzialność za innych. Tymczasem świat w rzeczywistości jest piękny pośród najprostszych rzeczy. Autentycznie praktykowana miłość daje prawdziwe szczęście, potrzebne jest jednak odkrywanie ciągle na nowo Bożego zamysłu i podejmowanie decyzji dotyczących konkretnych działań zgodnie z nim 9

Pośród różnych wypowiedzi kongresowych mówców na uwagę zasługuje wypowiedź doktora Daniela I. Marka, odnosząca się do właściwego przeżywania relacji w małżeństwie i w życiu rodzinnym. Podkreślał on zaraz na początku swego wystąpienia, jak zresztą wielu prelegentów na tym kongresie, wspaniałe dary Boga. Mówił o wielkiej Bożej miłości, wyrażającej się w stworzeniu i odkupie$n^{10}{ }^{10}$. To Stwórca dokonał rozróżnienia między mężczyzna i kobietą. Różnice obejmują różne sfery: biologiczną, genetyczną, fizyczną i psychiczną. Konsekwencją tego stanu rzeczy jest inna praca mózgów oraz inny rodzaj inteligencji, emocjonalności, seksualności czy też wrażliwości kobiet i mężczyzn. Niezwykle istotnym komponentem

9 Por. A. P r y c e (red.), World Meeting of Families - Philadephia 2015, dz. cyt., s. 37.

10 Tamże, s. 46. 
współtworzącym człowieka jest dar seksualności, który właściwie przeżywany otwiera człowieka na Boga i na drugą osobę. W tej różnorodności mężczyzna i kobieta są komplementarni, wzajemnie się uzupełniają. Człowiek ma wpisane w swoją naturę dążenie do jedności, a szczególnym miejscem do osiągnięcia tej jedności jest małżeństwo, ponieważ sakramentalni małżonkowie staja się jednym ciałem. Nie żyją jednak tylko dla siebie, ale także dla Chrystusa, winni więc stawać się świętymi w tej podstawowej wspólnocie, jaką jest małżeństwo i rodzina. To z miłości ich dwojga, ich wzajemnego oddania mają pojawić się dzieci, będące owocem tej miłości. Pojęcie miłości nie może jednak odnosić się tylko do przeżywania relacji intymnych pomiędzy mężczyzną i kobietą. Miłość w małżeństwie jest czymś więcej niż tylko doświadczeniem seksualnego kontaktu czy samej prokreacji. Miłość ta wiąże się z dążeniem małżonków do osiągnięcia przez nich świętości, w ramach której jako rodzice pragną również wprowadzić dzieci do Królestwa Bożego. Punktem wyjścia w tej miłości jest prawidłowa relacja z Bogiem. Dzięki niej bowiem można zrozumieć współmałżonka, przebaczyć mu, dążyć do jedności, pogłębiając jednocześnie miłość do niego i do innych członków rodziny. Do realizacji tych zadań potrzebny jest zarówno czas na modlitwę, jak i czas przeżywany w rodzinie ${ }^{11}$.

Doktor John S. Grabowski, mówiąc o wzrastaniu w cnotach, inspirował słuchaczy do podjęcia pracy nad sobą w drodze do świętości, do której powołani są wszyscy ludzie ${ }^{12}$. Pomocą w realizacji tego powszechnego powołania są w Kościele sakramenty. Mówca, powołując się na przykłady świętych, zachęcał do nieustannej modlitwy, do dzielenia się radością z najbliższymi, szczególnie w rodzinie. Ponadto

11 Kradynał Lus Tagle arcybiskup Manili mówił do zebranych uczestników kongresu podczas sesji plenarnej: „Ludzie mogą mieć duży, piękny dom, ale nadal być bezdomnymi, ponieważ nie metraż jest najważniejszy, a dar obecności i miłości w rodzinie”. Było to niezwykle trafne spostrzeżenie nawiązujące do natury ludzkiej. Człowiek jest stworzony z miłości i do miłości, a ta może zaistnieć we wspólnocie osób. Tamże, s. 48.

12 Por. Sobór Watykański II, Konstytucja dogmatyczna o Kościele Lumen Gentium, nr 39, Watykan 1964. 
zapraszał do używania dobrych, budujących słów, do wzajemnego przepraszania się oraz proszenia o wybaczenie. Tym samym chciał zwrócić uwagę uczestników kongresu, powołując się na papieża Jana Pawła II, na to, jak ważną sprawą jest miłość w praktyce życia ${ }^{13}$.

Pośród wielu wystąpień szczególnie istotne są dwa wygłoszone podczas jednej sesji plenarnej pt. „Radość Ewangelii Życia”. Pastor Richard Warren zwrócił uwagę na fakt, że wartości związane z małżeństwem i rodziną współcześnie są dewaluowane. Właśnie dlatego rodziny potrzebują odnowy życia i wzmocnienia. Jest to możliwe poprzez zwrócenie się do Boga, który jest Miłością. Mówca apelował do zebranych, by pozwolili się kochać przez Boga, a następnie, by odwzajemnili tę miłość, przekazując ją jednocześnie w rodzinie. To „rodziny przepełnione radością wypełniają swoją misję, którą jest miłość" 14 .

Kardynał Seán Patrick O’Malley w odpowiedzi na wystąpienie pastora Warrena apelował o to, by rodziny stawały się tym, czym być powinny. Będzie to możliwe wówczas, gdy rodziny będą żyły tym, co głoszą. Dobre i piękne życie w rodzinie w oparciu o Boże Słowo i sakramenty jest formą wzajemnej ewangelizacji, która jest współcześnie tak bardzo potrzebna. Nie wystarczą same programy duszpasterskie, potrzeba jeszcze głoszonego z mocą Słowa ${ }^{15}$.

W czasie kongresu miało miejsce prawie 120 wystąpień różnych prelegentów. Charakterystyczne było też to, że prawie 40 procent stanowili przedstawiciele innych wyznań chrześcijańskich. Podejmowane w czasie kongresu tematy dotyczyły różnych zagadnień istotnych dla rodzin żyjących współcześnie. Pośród nich można wymienić te, które dotyczyły antropologii teologicznej, Ewangelii rodziny, relacji pomiędzy mężczyzną i kobietą, wychowania dzieci,

${ }^{13}$ Zob. Jan P a w e $\nmid$ II, Adhortacja apostolska Familiaris consortio, nr 49, Watykan 1981.

${ }^{14}$ Por. A. P r y c e (red.), World Meeting of Families - Philadephia 2015, s. 53, dz. cyt..

15 Por. tamże. 
niepełnosprawności, roli dziadków w rodzinie, sytuacji trudnych i nieprawidłowych w rodzinie czy też śmierci najbliższych.

Arcybiskup O’Malley spuentował swoje wystąpienie słowami, które mogą być puentą odnoszącą się do całego kongresu: Sukcesem kongresu będzie zmiana życia jego uczestników,

\section{ZAKOŃCZENIE}

Kolejny, VIII Międzynarodowy Kongres Rodziny, który odbywał się w ramach Światowego Spotkania Rodzin w Filadelfii, pokazuje, że tego typu wydarzenia są bardzo potrzebne. Było to bowiem piękne świętowanie prawdy na temat małżeństwa i rodziny. Głoszenie tej prawdy jest współcześnie niezwykle potrzebne, bardziej niż kiedykolwiek w historii. Istnieje ogromna potrzeba przypominania Bożego zamysłu względem małżeństwa i rodziny. Kongres doskonale spełnił to zadanie, ponadto wydarzenie to było wielką promocją prawdy o rodzinie. Stąd też można bez wahania stwierdzić, że warto angażować wiele osób i środków materialnych, by proklamować Ewangelię rodziny.

Trzeba jednocześnie zauważyć, że kongres był inspiracją dla uczestników, pośród których byli ludzie zaangażowani w różnego rodzaju pożyteczne działania na rzecz małżeństwa i rodziny. Entuzjazm pojawiający się w związku z usłyszanym Słowem, którym jest Ewangelia rodziny oraz interesujące pomysły na pracę z małżeństwami, rodzinami, jak również i wewnątrz rodzin, stanowią inspirację do zaangażowania uczestników tego spotkania w pracę na rzecz rodziny w społecznościach lokalnych. Wszystko to wzbudza zapał do pracy na rzecz posługi wobec sakramentalnych małżonków, jak również wobec tych, którzy znajdują się w sytuacji trudnej i nieprawidłowej ${ }^{16}$.

Kongres rodzin w Filadelfii przypomniał, że proklamowanie chrześcijańskiej wizji małżeństwa i rodziny jest w dobie obecnej niezwykle istotne. Ma ona bowiem ogromne znaczenie dla prawidłowego

${ }^{16}$ Por. J a n P aw e ł II, Adhortacja apostolska Familiaris consortio, nr 80-84, Watykan 1981. 
funkcjonowania samego małżeństwa i rodziny, jak również, w szerszej perspektywie, dla całego społeczeństwa. Stąd też należy dołożyć starań, by bronić tożsamości rodziny, tak aby mogła ona stawać się tym, czym być powinna. Niezbędne wydaje się w tej sytuacji, aby bronić jej podstawowych i należnych praw. Jest to zadanie, które należy w pierwszym rzędzie do państwa i społeczeństwa, którego jest żywą komórką. Szczególna odpowiedzialność w tym względzie spoczywa na politykach tworzących prawo. Winni oni uwzględnić wszystko to, co wiąże się z prawidłowym funkcjonowaniem małżeństwa i rodziny. Ma to bowiem niebagatelne znaczenie dla funkcjonowania społeczeństwa. Nie mogą więc mylić instytucji małżeństwa mężczyzny i kobiety, jak również rodziny, z innymi instytucjami życia społecznego. Tak rozumiana rodzina winna być pod każdym względem chroniona. Powinno się jednocześnie podejmować szereg działań prewencyjnych, które by umacniały rodzinę w jej prawidłowym funkcjonowaniu, a tworzone prawo winno wspierać ten sposób myślenia.

Rodziny winny również angażować się w tworzenie kultury i polityki im sprzyjającej. To zadanie mogą realizować poprzez tworzenie stowarzyszeń, organizacji i wspólnot, które pomogą w kreowaniu dobrego prawa ${ }^{17}$. Chodzi więc o mądre angażowanie się w politykę poprzez lobbowanie na rzecz korzystnych z punktu widzenia rodzin rozwiązań. Dla skuteczności tych działań konieczne jest angażowanie się małżonków i rodziców w stowarzyszenia zajmujące się tego typu działalnością. Ten sposób myślenia znalazł aprobatę w nauczaniu Jana Pawła II, do którego warto się ciągle odwoływać. Papież w swojej znakomitej adhortacji o zadaniach rodziny chrześcijańskiej pisze: jest „wskazane ażeby rodziny chrześcijańskie w żywym poczuciu wspólnego dobra czynnie angażowały się na każdym poziomie w (...) stowarzyszenia nie kościelne. Niektóre z takich stowarzyszeń zajmują się ochroną, przekazywaniem i pielęgnowaniem zdrowych wartości

17 Papież Jan Paweł II w adhortacji apostolskiej Familiaris consortio zachęcał rodziny chrześcijańskie do angażowania się w pracę również stowarzyszeń nie kościelnych. Zob. tamże, nr 72. 
etycznych i kulturowych danych ludów, rozwojem osoby ludzkiej, opieką lekarską, prawną i socjalną matki i dziecka (...). Inne dążą do budowania świata sprawiedliwego i bardziej ludzkiego, do postępu w zakresie słusznych praw, które sprzyjałyby właściwemu porządkowi społecznemu przy pełnym poszanowaniu godności i każdej słusznej wolności jednostki i rodziny na poziomie narodowym albo międzynarodowym (...)"18. Wydaje się więc niezwykle słusznym angażowanie ludzi sumienia $\mathrm{w}$ działalność polityczną celem tworzenia takiego prawa, które będzie służyło małżeństwu, rodzinie i całemu społeczeństwu.

Same rodziny winny także angażować się w tworzenie kultury im sprzyjającej. Formacja, angażowanie się w życie parafii, także poprzez tworzenie wspólnot pomagających małżeństwom i rodzinom w ich prawidłowym kształtowaniu. To zaangażowanie wynika z powszechnego obowiązku dążenia do świętości na drodze duchowości sakramentu małżeństwa.

Kongres w Filadelfii był intelektualnym namysłem nad zagadnieniem dotyczącym różnych kwestii związanych z małżeństwem i rodziną. Był to też czas świadectw wielu prelegentów i występujących w dyskusjach uczestników. Wszystko to było jednocześnie inspiracją do zaangażowania się uczestników tego spotkania w pracę na rzecz małżeństwa i rodziny.

Małżeństwo i rodzina jest wartością samą w sobie. Żyje ona pełnią życia wówczas gdy kocha. Jest to podstawowe przesłanie Międzynarodowego Kongresu Rodziny dla całego świata.

\section{Streszczenie}

We wrześniu 2015 roku w ramach VIII Światowego Spotkania Rodzin odbył się w Filadelfii Międzynarodowy Kongres Rodzin pod hasłem „Miłość jest naszą misją: rodzina pełnią życia". Pragnieniem organizatorów było, aby to spotkanie przyniosło wspaniałe owoce polegające na odnowieniu życia poszczególnych osób

\footnotetext{
18 Tamże.
} 
oraz całych rodzin. Uczestnicy omówili trudności, z jakimi borykają się rodziny w dzisiejszym zlaicyzowanym świecie i wskazali, że rozwiązanie ich nie jest możliwe bez zwrócenia się ku Bogu. Podkreślili znaczenie właściwego przeżywania relacji w życiu rodzinnym, ponieważ Bóg stworzył człowieka do życia we wspólnocie miłości. Proklamowano chrześcijańską wizję małżeństwa i rodziny. Przesłaniem kongresu była myśl, że rodzina żyje pełnią życia wtedy, gdy kocha, ponieważ jej misją jest miłość.

\section{Love as a Family Mission. Reflections based on the Debate of VIII International Congres of the Family in Philadelphia Summary}

In September 2015 as part of VIII World Meeting of Families, an International Congress of Families was held in Philadelphia under the slogan "Love is our mission: family gives the fullness of life." The desire of the organizers was that this meeting has brought remarkable fruits consisting of the renewal of life of individuals and families. The participants discussed the difficulties faced by families in today's secularized world, and indicated that their solution is not possible without turning to God. They stressed the importance of proper living relationships in family life, because God created man to live in a community of love. Christian vision of marriage and family was proclaimed. The message of the congress was the idea that the family lives a full life when it is full of love, because its mission is love.

\section{Bibliografia:}

Jan Paweł II, Adhortacja apostolska Familiaris consortio, Watykan 1981. Jan Paweł II, List do rodzin Gratissimam sane, Watykan 1994

Pryba A., Rodzina szkoła wartości ludzkich i chrześcijańskich w świetle przestania

VI Światowego Spotkania Rodzin (Meksyk 2009), w: A. Pryba (red.), Rodzina szkołq wartości, Poznań 2011, s. 155-164.

Pryce A. (red.), World Meeting of Families - Philadephia 2015, Philadephia 2015. Sobór Watykański II, Konstytucja dogmatyczna o Kościele Lumen Gentium, Watykan 1964. 